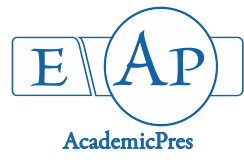

\title{
Root Structure and Belowground Biomass of Hybrid Poplar in Forestry and Agroforestry Systems in Mediterranean France
}

\author{
Kaushalendra Kumar JHA* \\ UMR Systems, L'Institut National de la Recherche Agronomique, 2 place Pierre Viala, 34060 Montpellier, France; jhakk1959@gmail.com \\ ${ }^{*}$ Current address: Indian Institute of Forest Management, Bhopal 462003, MP, India
}

\begin{abstract}
In poplar, one of the most used species of forestry and agroforestry, below ground biomass allocation plays an important role in providing anchorage as well as efficient nutrient and water distribution channel. Available literature on this aspect is not enough in hybrid Poplar, Populus euramaricana I-214. Therefore, the study was aimed at finding how this species developed its root system and how much belowground biomass was allocated in Forest System (FRS) and Agroforest System (AFS). This was done using soil excavation and root coring methods. Coarse roots were distributed in all directions but their number and proximal cross section area (CSA) were not uniform. In the case of AFS tree maximum CSA was distributed in the south and south-west direction while in FRS it was in the north-east and south-east direction. Fine roots were observed throughout the rooting zone along with coarse and medium roots up to a maximum depth of $2.4 \mathrm{~m}$ in FRS and $2.8 \mathrm{~m}$ in AFS. Total belowground biomass was higher in AFS tree $\left(130 \mathrm{~kg}\right.$ tree $\left.^{-1}\right)$ than FRS tree $\left(120 \mathrm{~kg} \mathrm{tree}^{-1}\right)$. But on hectare basis FRS accumulated $\left(24.5 \mathrm{Mg} \mathrm{ha}^{-1}\right)$ more biomass than AFS $\left(18.1 \mathrm{Mg} \mathrm{ha}^{-1}\right)$. However, if practiced in surplus agriculture area and considered the system as a whole, AFS allows grain production in lieu of some biomass deficit.
\end{abstract}

Keywords: I-214 clone, excavation and coring, Populus euramaricana, root orientation, rooting depth

\section{Introduction}

Poplars have consistently been part of the agriculture and forest resource sectors in temperate regions as well as tropical country like India where cotton wood has been introduced substantially as block plantation and extensively as agroforestry crop (Jha, 1999; Block et al., 2006; Chauhan et al., 2012; Gera, 2012). Immediate and long-term needs in both the agriculture and forest resource sectors have created a niche for the production of wood from managed plantations of native poplar species and their hybrid varieties (Jha, 1999; Block et al., 2006). In agricultural landscapes, the implementation of agroforestry systems has the potential to provide a high carbon sequestration capacity compared to other greenhouse gas mitigation strategies (Jose and Bardhan, 2012).

Short rotation forestry crops are currently assuming growing importance in many countries where surplus agriculture and other land is becoming available and poplar stands are expanding on them, for example, Bulgaria, Canada, China, Germany, Serbia, Spain, USA etc. (Calfapietra et al., 2010). The aim is to benefit from the goods directly and services like carbon sequestration indirectly. This system has covered thousands of hectares in
Europe alone to generate renewable energy, mostly using poplars and willows (Herve and Ceulemans, 1996; Venendaal et al., 1997; Verwijst, 2001; Langeveld et al., 2012). European farmers are increasingly attracted to energy crops following the most recent changes in the common agricultural policy and rapid development of the bioenergy sector (Spinelli et al., 2008). Wider use of poplar can contribute to European Union goals to ensure 20\% of its energy consumption from renewable resources until 2020 and continue further in the future (Jansons et al., 2014). Poplar based agroforestry has the capability of enhancing soil organic carbon up to $83 \%$ (Singh et al., 1989).

Longer duration carbon locking role is played by the root system of the vegetation (Kumar et al., 2006; Nair et al., 2009) which has some other roles, like nutrient and water acquisition, anchoring etc. Fine and coarse roots are key contributors to belowground net primary productivity, and play critical roles in the biogeochemical cycling of forest and woodland ecosystems (Clark et al., 2001; Brunner and Godbold, 2007; Malhi et al., 2011; Smith et al., 2013; Raich et al., 2014). The storage capacity and the rate of carbon sequestration in this biogeochemical cycle depend on various factors such as the climate, soil type, tree species used for afforestation, current forestry practices, pre-afforestation management and land use history (Post and Kwon, 2000; Paul et al., 2002). 
Among all roots, fine roots represent only a small fraction of total tree biomass, but fine root production and turnover are significant components of the biomass turnover (Amthor, 1986; Lambers et al., 2000; Chen et al.2 2004; Al Afas et al., 2008). Coarse roots are multifunctional tree components providing key functions such as transport (nutrients, photosynthate, water), storage (sugars and nutrients), biomechanical stabilization, as well as the framework upon which fine root develop and connect (Resh et al., 2003; Guo et al., 2013; Cook and Weigh, 2005).

Aboveground biomass in poplar plantations or forestry system (FRS) and agroforestry systems (AFS) has been widely studied around the world (Laureysens et al., 2004; Zabek and Prescott, 2006; Fang et al., 2007; Christersson, 2010; Fortier et al., 2010; Truax et al., 2012; ). In spite of crucial role of belowground parts for woody biomass production and carbon sequestration in soil (Berhongaray et al., 2015), fewer or disproportionate studies have evaluated the belowground biomass of these systems (Fortier et al., 2013). In other words, the poplar root system still remains the most poorly studied and understood portion of the tree (Friend et al., 1991). Therefore, the objectives of the present study conducted in AFS and FRS in Mediterranean region of France was to assess and compare (i) distribution of belowground biomass to fine, medium and coarse roots, (ii) orientation of coarse roots around the stump root, (iii) extent of vertical and horizontal spread of roots in soil and (iv) the advantage of one system over the other.

\section{Materials and Methods}

\section{Study sites}

Two experimental plots, Forestry (Plantation) System (FRS or PLS) and Agroforestry System (AFS), were located side by side in the vicinity of Vezenobres township (Longitude $4^{\circ} 9^{\prime} \mathrm{E}$, Latitude $44^{\circ} 2^{\prime} \mathrm{N}$, elevation $138 \mathrm{~m}$ a.s.l.) in the Mediterranean region of France. The soil was sandy alluvial fluvisol with $8 \%$ clay, $42 \%$ silt and $50 \%$ sand. Pure sand and gravel layers occurred at different depths, about 1.1-1.3 $\mathrm{m}$ and 2.5-2.9 $\mathrm{m}$. The climate is sub-humid with an average temperature of $14.8{ }^{\circ} \mathrm{C}$ and an average annual rainfall of $1172 \mathrm{~mm}$. Potential evapotranspiration (580 $\mathrm{mm}$ ) was higher than average rainfall $(267 \mathrm{~mm})$ during the main growing season, May to August. Water table fluctuation was also common in the area (Mulia and Dupraz, 2006).

The AFS and FRS plots were established in 1996 using better performing I-214 and I-4551 clones of hybrid poplar (Populus euramericana). AFS trees were spaced $16 \mathrm{~m}$ (alley) x $4.5 \mathrm{~m}$ (row) while FRS trees had spacing of $7 \mathrm{~m} \mathrm{x} 7 \mathrm{~m}$. The trees were pruned at $6 \mathrm{~m}$ and $10 \mathrm{~m}$ following a block design. Durum wheat was grown in AFS keeping fallow every 3 or 4 years. P. euramericana I-214 clone with $6 \mathrm{~m}$ pruning was selected for the present study in 2009. For the last 3 years the AFS plot was devoid of agriculture.

\section{Tree sample selection}

Tree harvesting and dry matter estimation method was selected for structure and biomass estimation of roots. Since harvesting method is time and resource consuming but more accurate, a trade-off was made and instead of multiple trees, single tree harvesting (Fang et al., 1999) was done in both AFS and FRS during summer 2009. Tree selection was done on following parameters: (i) tree was representative of the plantation having average diameter at breast height of all the trees in the plantation, (ii) it was from inner area not the border of the plantation, (iii) it's neighbouring trees had normal form and vigour and (iv) both the trees were of same clone (I-214) and same treatment (6 m pruning). Selected AFS tree matched all these qualifications in toto, but FRS tree was of little higher girth $(1.41 \mathrm{~m})$ than average $(1.36 \mathrm{~m})$ of the plantation. Therefore, biomass calculation for FRS was normalized by a factor 0.93 (square of the ratio of average tree and harvested tree) in this case (Jha, 2017).

\section{Root harvesting}

Stump and different types of roots were harvested at different depth and breadth in soil. Although multiple methods of belowground biomass harvesting have been recommended (Addo-Danso et al., 2016), excavation method was used for harvesting of roots to capture lateral root variability in larger volume of soil (Berhongaray et al., 2015). One quarter of the rooting zone of a single tree from both the plantations was selected randomly for excavation (Fortier et al., 2015b). This zone was divided into 2D voxels (volume elements of soil, analogous to pixels of $1 \mathrm{~m}$ length $\mathrm{x}$ $1 \mathrm{~m}$ breadth $\mathrm{x} 0.5 \mathrm{~m}$ depth) by marking squares $\left(1 \mathrm{~m}^{2}\right)$ on the ground. All the voxels were given unique identification number, for example first voxel with the tree stump in the centre had 0,0,0 identity and adjacent voxels had 1,0,0 on X axis (row), $0,1,0$ on $Y$ axis (alley) and $0,0,0.5$ on $\mathrm{Z}$ axis.

Harvesting was done from selected voxel columns (Fig. 1) starting from the farthest one near the excavation trench so that the task of removal of cut soil remains easy. These voxel columns were dug carefully using soil pick (MBW, Slinger, WI, USA) releasing high pressure air (125 PSI). Roots collected from each voxel were brought to the laboratory and categorised into three groups based on size. Although roots are categorized and named differently (Lodhiyal et al., 1995; Laclau, 2003; Tufekcioglu et al., 2003; Das and Chaturvedi, 2005; Fortier et al., 2015a), three categories viz., fine roots $(<2 \mathrm{~mm})$, medium size roots $(2 \mathrm{~mm}$ to $10 \mathrm{~mm})$ and coarse roots $(>10 \mathrm{~mm})$ were adopted in the present study.

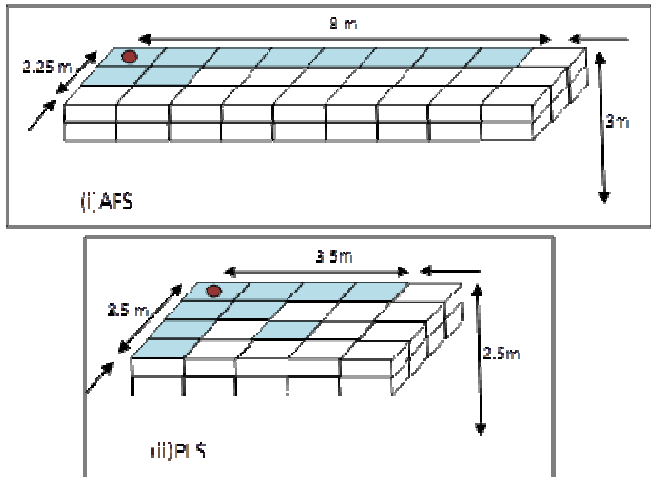

Fig. 1. The upper layer voxels and cellules $(1.0 \mathrm{~m} \mathrm{x} 1.0 \mathrm{~m} \mathrm{x}(0.5$ $\mathrm{m}+0.5 \mathrm{~m}$ ) in one quarter of root growing volume in (i) AFS and (ii) FRS (PLS). Blue boxes are root harvested cellules and brown ellipse is the stump position 
424

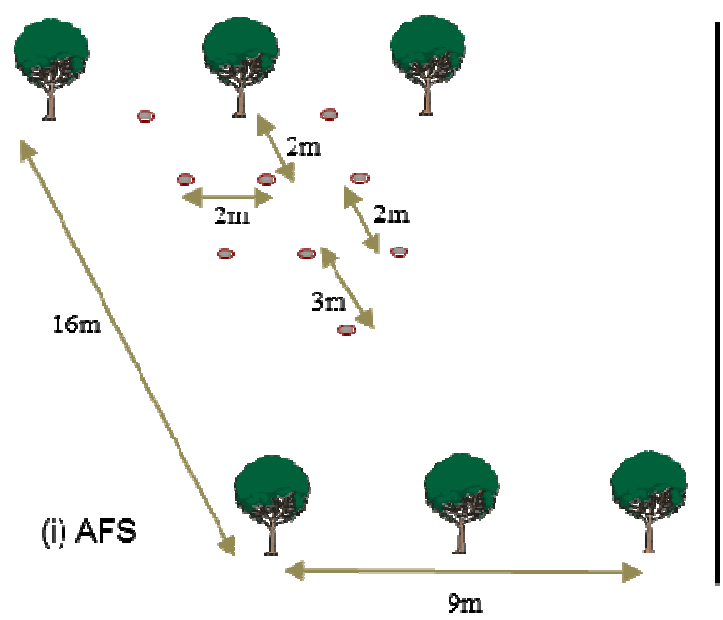

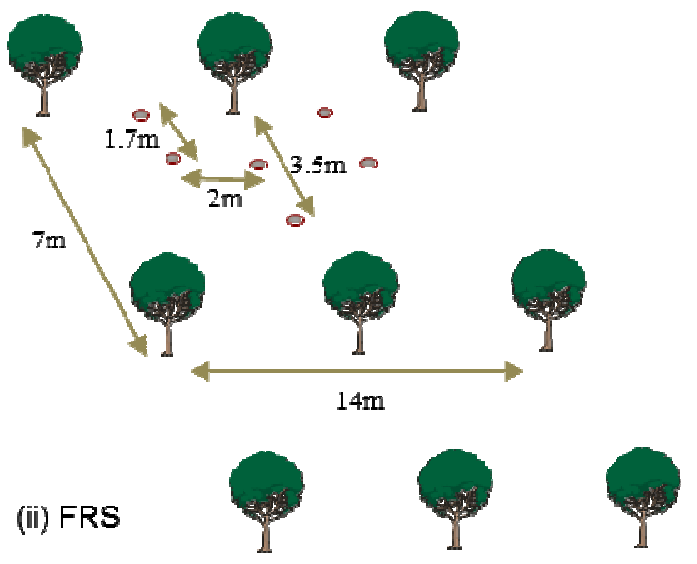

Fig. 2. Soil coring spots (brown ellipse between tree rows and close to the tree to be harvested) in (i) AFS and (ii) FRS of Populus euramaricana I-214. Distance in the drawing is not to the scale. Tree line, north-south, is the $\mathrm{X}$ axis and Alley is the $\mathrm{Y}$ axis

The stump root was excavated along with the proximal roots from first voxel column. All the secondary roots on the stumps were numbered and their proximal diameter or girth was recorded with reference to north, north east, east, south east, south, south west, west and north west directions using metal callipers or tailor's tape in order to determine their cross section area (CSA).

Soil coring method was also used in the present study for getting another set of fine root data since soil excavation method is reported to under estimate fine roots due to its loss during excavation (Friend et al., 1991) and recommendation of coring method for uniformly distributed fine roots (Mulia and Dupraz, 2006; Levillain $e t$ al., 2011). Nine and six well spread coring points were selected in the alley of AFS and FRS trees, respectively (Fig. 2). Coring was done using micro-caterpillar driller (Sondeuse EMCI 300C with core size $1.1 \mathrm{~m}$ by $0.1 \mathrm{~m}$ ). Soil cores were drilled out from maximum penetrable depth. The cores were divided into sub-cores of $0.2 \mathrm{~m}$ length and broken into two halves to observe presence of living and dead, fine and coarse roots. The live roots were smooth, light coloured and non-friable as compared to the dead roots. Roots were counted on both the faces of core breaks for further use.

\section{Root biomass estimation}

Harvested roots were cleaned, weighed and their samples were dried at $90{ }^{\circ} \mathrm{C}$ temperature in oven till constant weight. Fresh and dry weight ratio was used to calculate the biomass for harvested voxels. For remaining voxels biomass was extrapolated mathematically. As per site observation and trend in cellules' biomass, exponential decrease in root growth was assumed and exponential regression relationship between biomass and distance from the tree (along Y axis) was developed. Linear decrease was adopted along $X$ axis for want of enough of data and indicative trend with distance in AFS. Values of nonsampled cellules were calculated using the exponential decay equation constants (Sigma plot software). Weightage was applied to them cellule wise, since contribution of these were different for a quarter of the scene. Exponential decrease was used for both the axes $\mathrm{X}$ and $\mathrm{Y}$ in FRS. The biomass values calculated so far were corrected by using distance matrix, representing the voxels. In this case also weightage was applied in biomass calculation for the cellules. Quarter root biomass was arithmetically extrapolated to determine total underground biomass.

Fine root biomass by coring method was estimated using fine root number, density constant (143.55), specific root length $\left(17.86 \mathrm{~m} \mathrm{~g}^{-1}\right)$ and rooted volume in following formula (Mulia, 2005):

$$
\text { Root biomass }=\frac{\text { Aver age rootnumber } x \text { Rooted volume } x \text { Density constant }}{\text { Specilic root length }}
$$

\section{Results}

\section{Root structure and distribution}

Soil excavation showed that roots were growing horizontally as well as vertically. Secondary roots in both the trees grew on the stump root in all the directions (Fig. 3), but the orientation of these roots was not uniform in any of the quarters as opposed to the counterpart quarters in the azimuth. Their number, thickness and orientation by depth varied within the two trees. Total number of secondary roots was higher in FRS (140) than AFS (54) while total CSA of these roots were more in AFS $\left(3,243 \mathrm{~cm}^{2}\right)$ than FRS $\left(3,082 \mathrm{~cm}^{2}\right)$. Growth of stump root terminated bluntly before $1.5 \mathrm{~m}$ in FRS while it extended beyond $2.0 \mathrm{~m}$ in AFS giving the appearance of a tap root. The horizontal roots radiated farther beyond $7.0 \mathrm{~m}$ in AFS and $3.0 \mathrm{~m}$ in FRS. Vertical and oblique roots were also seen in some voxels far from the tree base.

The pattern of coarse root orientation on the stump root revealed that north-south orientation had more root CSA than east-west in both the trees. When intermediary orientation, north-east and north-west, and south-east, and south-west were combined, root area distribution stood lopsided. In the case of AFS tree, maximum distribution was in south and south-west direction while in FRS it was north-east and south-east direction (Fig. 3 a \& b). The voxel-wise CSA distribution was $64 \%, 10 \%$ and $26 \%$ in 0 $50 \mathrm{~cm}, 51-100 \mathrm{~cm}$ and $100-150 \mathrm{~cm}$ depth, respectively, in 
(a)

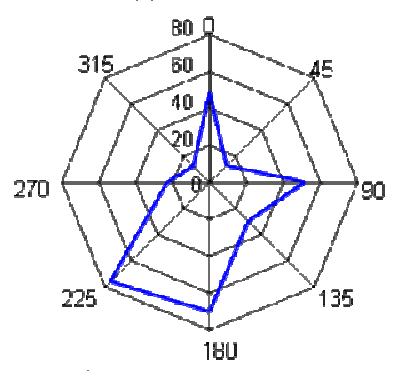

(c)
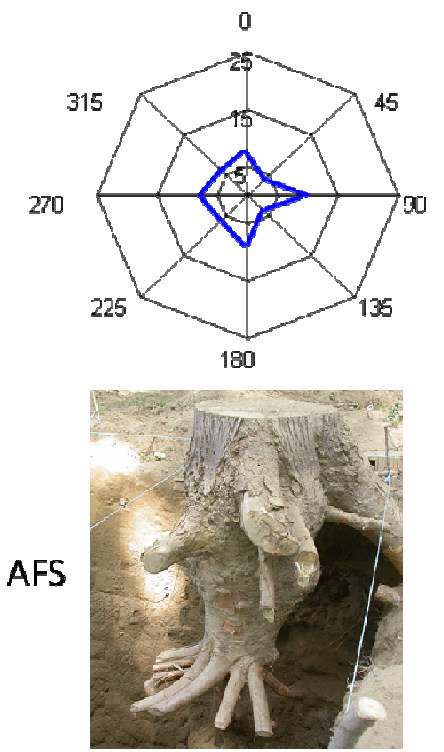

(b)

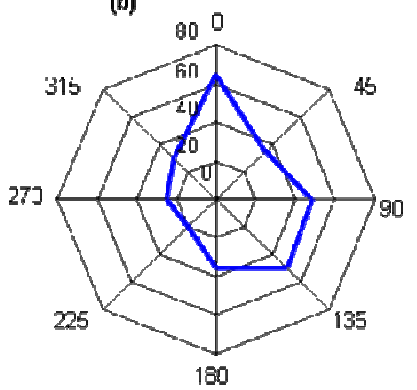

(d)

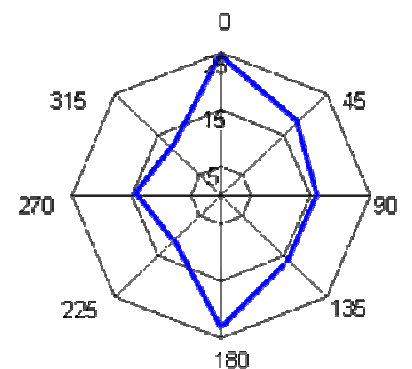

60

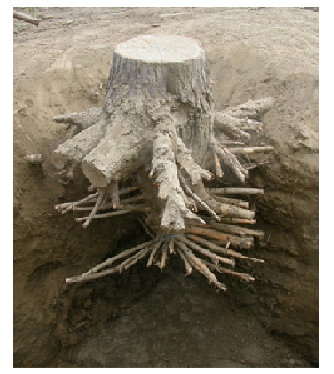

FRS

Fig. 3. Graphic and pictorial presentation of root profile in stump voxel column of AFS and FRS trees. Root cross section area is represented in (a) and (b), and Root number is represented in (c) and (d), respectively of AFS and FRS trees. 0 degree symbolizes north direction

the case of AFS while it was $73 \%, 17 \%$ and $10 \%$ in FRS. However, morphological observation of root orientation indicated that secondary roots were prominently coming out of stump root in two tiers in AFS tree with a gap of 60$70 \mathrm{~cm}$, first tier closer to the ground and second at the bottom of stump root. There were very few secondary roots growing on the stump root between the two tiers (Photos in Fig. 3). In FRS no such tier differentiation was evident since the secondary roots were growing in continuity all along the stump root.

Fine roots were observed throughout the rooting zone along with coarse and medium roots. They were excavated from sub-surface $(10 \mathrm{~cm})$ up to a maximum depth of $2.4 \mathrm{~m}$ in FRS and $2.8 \mathrm{~m}$ in AFS. However, rooting depth was variable along the horizontal distance from the tree. It seemed to be increasing from tree line up to $1.7 \mathrm{~m}-2.0 \mathrm{~m}$ distance and afterwards there was decrease in rooting depth with increase in distance. Fine root density also varied at different depths without showing any trend of increase or decrease (Fig. 4).

\section{Belowground biomass distribution}

Tree height, girth, and density in AFS and FRS were $30.7 \mathrm{~m}, 1.39 \mathrm{~m}$ and 139 tree $^{-1} \mathrm{a}^{-1}$ and $30.7 \mathrm{~m}, 1.41 \mathrm{~m}$ and 204 tree ha $^{-1}$, respectively. Other results related to biomass are recorded in Table 1 . The assessment of different components of root biomass was based on regression equations developed from root biomass $(\mathrm{RB})$ and voxel distance $(Y)$ from the tree. All the six equations $\left(\mathrm{RB}=\mathrm{a}^{*} \exp (-\mathrm{bY})\right.$ related to trend-lines presented in Fig. 5 were highly significant $\left(\mathrm{r}^{2}=841^{* *}\right.$ to $\left.999^{* *}\right)$. Total belowground biomass was higher in AFS tree $\left(130 \mathrm{~kg} \mathrm{tree}^{-1}\right)$ than FRS tree $\left(120 \mathrm{~kg}\right.$ tree $\left.{ }^{-1}\right)$. The pattern was similar in other components also like fine roots, medium roots, coarse roots and stump root. Dry root mass allocation into different components like fine root, medium root, coarse root and stump root was $4 \%, 10 \%, 45 \%$ and $41 \%$, respectively in AFS tree. In the case of FRS tree, fine root and coarse root contribution remained same but medium root was $1 \%$ lower and stump root $1 \%$ higher. The two methods of fine roots' biomass estimation resulted in varied quantity. Coring (7.7 kg tree ${ }^{-1}$ AFS; $5.9 \mathrm{~kg}$ tree $^{-1}$, FRS) yielded higher biomass than excavation $\left(5.4 \mathrm{~kg}\right.$ tree $^{-1}$, AFS; $\left.4.6 \mathrm{~kg} \mathrm{tree}^{-1}, \mathrm{FRS}\right)$ in both the trees.

Biomass accumulation in rooting space of tree through fine roots depended on its density and length. However, density of fine roots was not consistent through depth of soil or distance from tree in both the cases of AFS and FRS (Fig. 4). AFS stored fine root biomass in to $2.8 \mathrm{~m}$ soil depth while in FRS storage depth was restricted to $2.4 \mathrm{~m}$. Fine root biomass storage (Fig. 6) in AFS varied from $0.96 \mathrm{~kg}(0$ $0.2 \mathrm{~m})$ to $0.05 \mathrm{~kg}(2.6-2.8 \mathrm{~m})$ while in FRS it varied from 
(a) Distance from tree line, $\mathrm{m}$

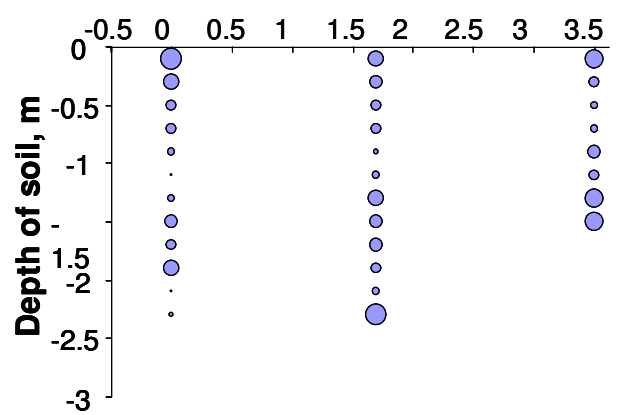

(b)

Distance from tree line, $\mathrm{m}$

\begin{tabular}{|c|c|c|c|c|c|c|c|c|}
\hline $0^{-1}$ & 0 & 1 & 2 & 3 & 4 & 5 & 6 & 7 \\
\hline & : & & 0 & & 0 & & & 0 \\
\hline-0. & 0 & & 0 & & 0 & & & 0 \\
\hline & 0 & & ० & & $\circ$ & & & 0 \\
\hline & $\circ$ & & 0 & & $\circ$ & & & $\circ$ \\
\hline-1 & 0 & & 0 & & 0 & & & \\
\hline & 0 & & 。 & & $\circ$ & & & \\
\hline-1.5 & 。 & & $\circ$ & & $\circ$ & & & • \\
\hline-2 & . & & 0 & & : & & & : \\
\hline & $\circ$ & & 。 & & • & & & 0 \\
\hline ถั -2.5 & 0 & & $\begin{array}{l}0 \\
0\end{array}$ & & 0 & & & \\
\hline-3 & & & & & & & & \\
\hline
\end{tabular}

Fig. 4. Fine root density (note the size of the blue bubbles) at different depth and distance from tree in FRS (a) and AFS (b) trees
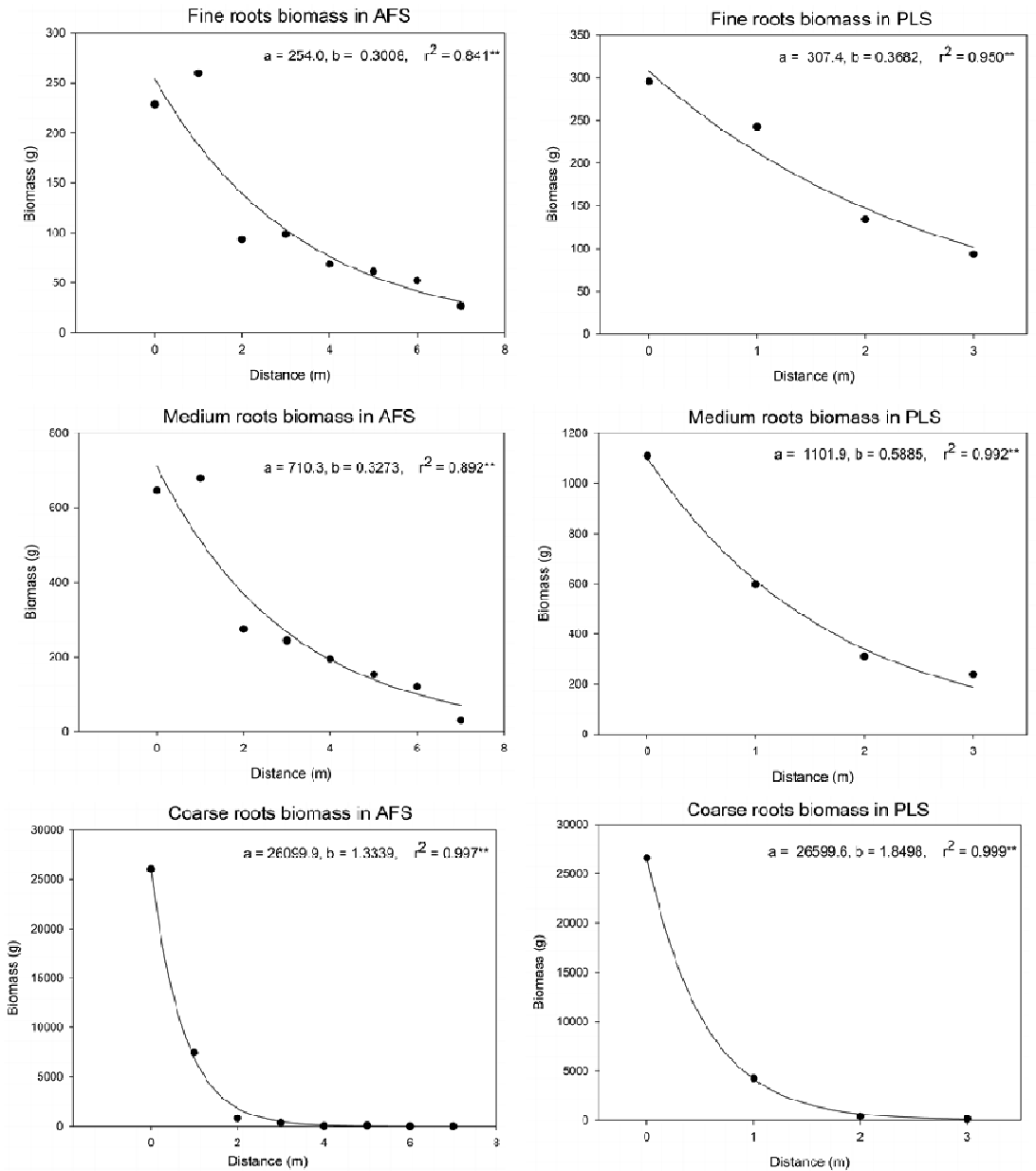

Fig. 5. Charts displaying biomass regression curve (exponential decay) along with corresponding intercept and slope values in AFS and PLS (FRS). X axis: distance from the tree and $\mathrm{Y}$ axis: root biomass

$1.07 \mathrm{~kg}(0-0.2 \mathrm{~m})$ to $0.15 \mathrm{~kg}(2.0-2.2 \mathrm{~m})$. However, generalization showed that there was maximum fine root biomass storage in first meter (48\% in AFS and $45 \%$ in FRS) followed by second meter (27\% in AFS and $40 \%$ in FRS) and then third meter (26\% in AFS and $15 \%$ in FRS).

\section{Discussion}

Root excavation method

Possible reason of higher fine root quantity estimation by coring than excavation in both the tress, AFS and FRS, could be explained by a hypothesis that excavation method results in sampling error since roots break off and get lost during excavation (Millikin and Bledsoe, 1999; Niyama et al., 2010). Bledsoe et al. (1999) also found that complete recovery of entire deep rooted system was difficult even under ideal condition. Similar to this, Friend et al. (1991) observed in $P$. trichocarpa $\times$. deltoides clones that field excavation failed to recover at least $68 \%$ of fine root 
Table 1. Synthesis of the biomass results in Agroforestry (AFS) and Forestry (FRS) Plantations

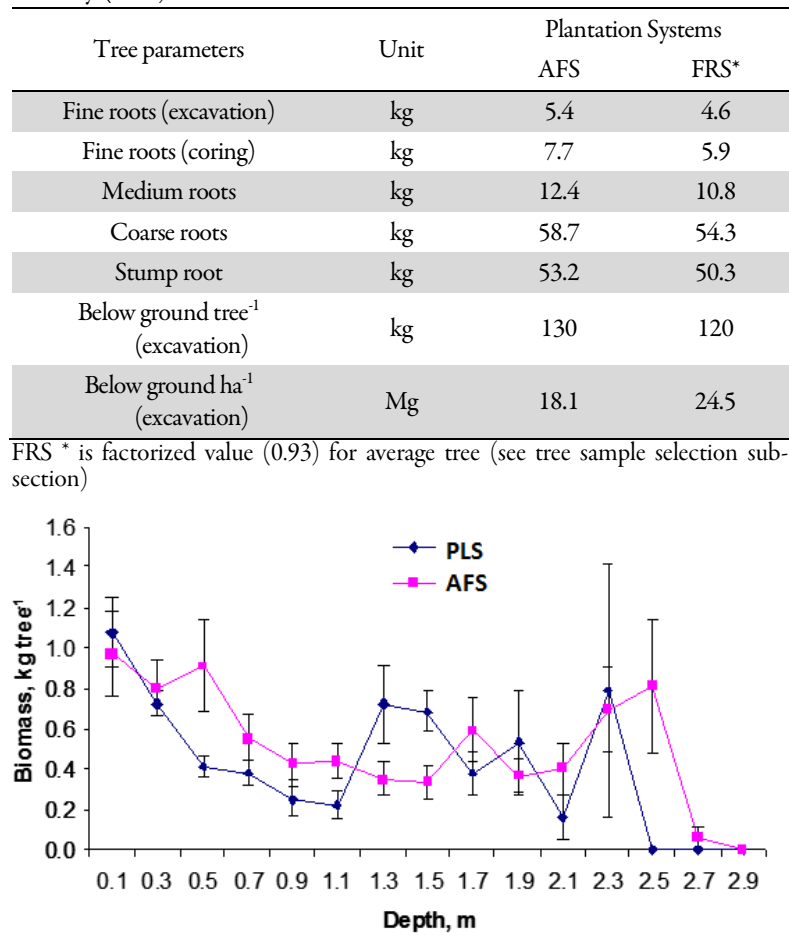

Fig. 6. Fine root biomass at different depth in AFS and PLS (FRS) trees

biomass. This loss appeared to be very high as compared to the present study where there was $70-77 \%$ recovery of fine roots in relation to coring method.

\section{Root harvesting depth}

Most of the workers, owing to resource and time consumption factor coupled with assumption of root presence in that area only, used excavation method and explored fine roots to limited depth, for example, $0.4 \mathrm{~m}$ (Ostonen et al., 2005), $0.5 \mathrm{~m}$ (Bayala et al., 2004), 0.3-0.5 m (Jiangen et al., 2008), $0.6 \mathrm{~m}$ (Tomlinson et al., 1998), $0.8 \mathrm{~m}$ (Moreno-Chacon and Lusk, 2004), 0.6-0.9 m (Misra et al., 1998), $1.0 \mathrm{~m}$ (Purbopuspito and Rees, 2002; Dowell et al., 2009), $1.5 \mathrm{~m}$ (Smith et al., 1999) and $2.0 \mathrm{~m}$ (Moreno et al., $2005)$ in different species. In the case of Poplar, few studies like, Puri et al. (1994), Fang et al. (2007) and McIvor et al. (2009) explored $0.3 \mathrm{~m}, 1.0 \mathrm{~m}$ and $1.4 \mathrm{~m}$ depth, respectively. However, in the present study, excavation was extended to $3.0 \mathrm{~m}$ depth since roots were observed up to $2.4 \mathrm{~m}$ to $2.8 \mathrm{~m}$ during coring. This finding is supported by Mullia and Dupraz (2006) and Heilman et al. (1994) who also recorded poplar roots up to $3.0 \mathrm{~m}$ and beyond this, respectively.

Hansen et al. (2003) and Rosengren et al. (2006) reported that $95 \%$ of all fine roots were located within 1.0 $\mathrm{m}$ in temperate and boreal forest ecosystems. Callesen $\mathrm{et}$ al. (2016) suggested this depth as pragmatic 'effective rooting depth' which is not in conformation with plantation systems in Mediterranean condition where medium roots and coarse roots were found much below this depth. Simple indication of present finding was that effective rooting depth should be beyond $1.0 \mathrm{~m}$, otherwise there could be omission of substantial amount of root recovery (52-55\%) since its distribution in first, second and third meter depth, respectively, was $48 \%, 27 \%$ and $25 \%$ in AFS and $45 \%$, $40 \%$ and $15 \%$ in FRS. As such estimation of these deeper layer roots, being out of the ploughing layer, are very important from the view point that they have longer residence time in the soil since they are better protected and undisturbed (Nair et al., 2009).

\section{Fine and coarse root distribution}

Fine roots were distributed in the deeper layer also but its concentration was higher in first layer $(0-10 \mathrm{~cm})$ in both AFS and FRS systems. Quite a few workers in Poplar (Dickman et al., 1996; Lukac et al., 2003; Al Afas et al., 2008) and other species like scot pine, Japanese cedar, Khasi pine etc. (Friend et al., 2000; John et al., 2001; Janssens et al., 2002; Konopka et al., 2005 \& 2006) also reported concentration of fine roots in upper layer. This variation of root concentration may be due to varied presence of coarse root, nutrient and moisture availability, soil structure, temperature and microbial activity in different soil layers. Interaction among these factors are more dynamic in subsoil region in comparison to deeper layer (Block et al., 2006; Konopka et al., 2006). Uneven distribution of roots in different directions or rooting quarters may have similar reasons.

Many researchers (Kellman, 1979; Watson and O'Loughlin, 1990; Puri et al., 1994, Abernathy and Rutherford, 2001; McIvor et al., 2005) concluded that structural roots are largely confined to top $0.3 \mathrm{~m}$ of soil profile in Poplar and other species. This understanding does not hold well in the present case since more than $50 \%$ of root biomass was distributed beyond this depth. However, there are a few more reports of deep seated coarse root distribution in cottonwood (Rood et al., 2011), loblolly pine (Albaugh et al., 2006), and dehesa vegetation (Moreno et al., 2005).

\section{Root orientation and growth}

Root number and CSA in Populus $x$ euramericana (Tasman variety) varied between different depths but not in different directions (McIvor et al., 2005). Contrary to this, these two varied with change in direction as well in the present study (Populus euramericana I-214). Although Smith (2001) and Kalliokoski et al. (2008) observed strong assumption of symmetrical dimension of root system, Puri et al. (1994) and McIvor et al. (2009) recorded highly asymmetric roots in poplar and other species owing to the effect of non-symmetrical mechanical stress and heterogeneous nutrient availability in soil (Coutts et al., 1999; Casper et al., 2003).

Root growth is essentially opportunistic in its timing and its orientation. It takes place whenever and wherever the environment provides water, oxygen, minerals, support and warmth (Perry, 1989). Variation of number in secondary roots and their proximal CSA in different directions in two different systems and even within the same tree of present investigation indicated that distribution of resources was not uniform. Substantial 
428

variation in root system has been previously reported in clonal plants of same age growing in uniform soil and site condition (Harrington and DeBell, 1996). Therefore, exploring the limited or one quarter of the rooting space of a tree (Fortier et al., 2015b), and extrapolation of the value from it may not give accurate estimation and lead into either overestimation or underestimation of root growth. Henderson et al. (1983) had also confirmed in Picea sitchinensis that no reliable estimate can be obtained from measuring only one quarter of the space.

Two tiered root orientation in the AFS tree, probably due to damage of upper layer roots during ploughing of inter-row space for agriculture, was reported earlier also in sandy location by Perry (1989) in Pinus and other trees. This was done strategically to absorb water and nutrients from surface layer by first tier. Deep seated second tier allowed survival under drought or other adverse condition. Rood et al. (2011) also observed that in drier regions the cottonwood becomes phreatophytic and produces deeper root system to access moisture from ground water.

\section{Belowground biomass}

Total root biomass (18.1 $\mathrm{Mg} \mathrm{ha}^{-1}$ in AFS and $24.5 \mathrm{Mg}$ $\mathrm{ha}^{-1}$ in FRS) was within the reported range (14.8 Mg ha ${ }^{-1}$ to $29.6 \mathrm{Mg} \mathrm{ha}^{-1}$ ) of hybrid poplar buffer (Fortier et al., 2013) but fine root biomass $\left(0.75 \mathrm{Mg} \mathrm{ha}^{-1}\right.$ in AFS and $0.94 \mathrm{Mg} \mathrm{ha}^{-1}$ in FRS) was very low (1.86 $\mathrm{Mg} \mathrm{ha}^{-1}$ to $2.62 \mathrm{Mg} \mathrm{ha}^{-1}$; Fortier et al., 2015a). The condition was similar as compared to other systems like, young tree plantation $\left(6 \mathrm{Mg} \mathrm{ha}^{-1}\right.$ to 42 $\mathrm{Mg} \mathrm{ha}^{-1}$; Lukac et al., 2003 and Block, 2004) and mature forest (5 Mg ha ${ }^{-1}$ to $52 \mathrm{Mg} \mathrm{ha}^{-1}$; Steele et al., 1997 and Pinno et al., 2010). Though the edapho-climatic factors govern biomass production, the reason for higher fine root biomass could be higher plantation density as hypothesised by Berhongaray et al. (2013). This was confirmed in present study also as FRS had higher density and fine root biomass than AFS.

However, higher fine root or total root biomass on per tree basis in AFS than FRS could be due to different management regime. FRS trees got only post-planting silvicultural treatment like pruning while AFS got additional advantage of environment manipulation like irrigation and fertilizer application to the alley crop. Latter had also lesser inter-tree competition for underground resources like nutrients and moisture. Jha and Gupta (1991) and Banerjee et al. (2009) have also suggested that providing extra irrigation, fertilizer doses, weeding and hoeing during the early age of intercropping enhanced tree growth resulting in more biomass accumulation (Singh and Sharma, 2007). Corroborating results were found in other studies like, agrisilviculture (Pingale et al., 2014), fruit trees (Raizada et al., 2013), young Populus deltoides plantation (Kern et al., 2004) and Acacia mangium (Danial et al., 1997).

\section{Forest and agroforest systems}

The root system of two differently nurtured trees was different on accounts of coarse root orientation and resource allocation in spite of being same clone, age and locality. AFS showed more plasticity due to changed culture regime. This is in line with the hypothesis of Mulia and Dupraz (2006) that trees grown in association with annual winter crops develop a different rooting pattern as compared to trees grown in pure forestry stands. Root depth and architecture are partly controlled by physical and agronomic factors (Bishopp, 2009; Fukaki and Tasaka, 2009) but substantially by the genotype and age (Wullschleger et al., 2005; Kell, 2012). But in the present case genetic control hypothesis for biomass variation could be ruled out (both trees same clone and age), and be assigned to soil structure and nutrient availability. Additional factor for deep rooting could also be the available moisture in water table around $3.0 \mathrm{~m}$ level. There is indirect support from Hallgren (1989) that poplar is an opportunistic rooter and does not produce deep roots if water table is at higher level.

As discussed earlier coarse and fine roots of poplar in plantation and agroforestry system are located near soil surface (Tufekcioglu et al., 1999; Douglas et al., 2010 etc.) with $1.0 \mathrm{~m}$ as effective rooting depth (Callesen $e$ al., 2016) may have some limitation. Contrasting to this much deeper roots in the present case had an advantage of extracting nutrients and moisture from larger area as well as acting as safety net for trapping leachable nutrients from upper layer (Allen et al., 2004; Dougherty et al., 2009). On this account AFS is more useful than FRS since it had root spread more deep and wide. Plasticity of AFS roots, an adaptation feature (Perry, 1989), get support from Gary (2000) who speculated that ploughing effected pruning of lateral roots could be the reason to drive down the coarse root to deeper layer since they were damaged and could not grow laterally beyond this in the tilled space. It is also possible that the presence of roots of agriculture crop played its role in this plasticity (Yocum, 1937; Mulia and Dupraz, 2006).

\section{Conclusions}

The hybrid poplar had deep seated root system in fluvisol in Mediterranean region. Coarse roots occupied the available space in all the directions but their orientation in a section may not be the mirror image of any of the quarter or the half of the rooting zone, possibly because of uneven soil structure and uneven nutrient availability. Differences were found in the trees of same species/clone at the same age but grown under two different systems - monoculture (FRS/PLS) and agrisilviculture (AFS). Secondary root orientation was tiered in the latter, possibly because of ploughing of tree inter-row space and presence of crop roots. Belowground allocation of biomass was higher in different root components - fine, medium and coarse roots in AFS tree. On hectarage basis it was more in FRS mainly due to higher tree density and optimum use of available nutrients. If introduced in agriculture land AFS has the advantage of grain production with some compromise on biomass vis a vis FRS.

\section{Acknowledgements}

The European Union and INRA, Montpellier are thanked for financial support. The author is also thankful to Dr Christian Dupraz, INRA, Montpellier, France for providing opportunity to work in his laboratory. 


\section{References}

Addo-Danso SD, Prescott CE, Smith AR (2016). Methods for estimating root biomass and production in forest and woodland ecosystem carbon studies: A review. Forest Ecology and Management 359:332-351.

Abernethy B, Rutherfurd ID (2001). The distribution and strength of riparian tree roots in relation to riverbank reinforcement. Hydrological Processes 15:63-79.

Al Afas N, Marron N, Zavalloni C, Ceulemans R (2008). Growth and production of a short-rotation coppice culture of poplar - IV: Fine root characteristics of five poplar clones. Biomass and Bioenergy 32:494502.

Albaugh TJ, Allen HL, Kress WL (2006). Root and stem partitioning of Pinus taeda. Trees: Structure and Function 20:176-185.

Allen SC, Jose S, Nair PKR, Brecke BJ, Nkedi-Kizza P, Ramsey CL (2004). Safety-net role of tree roots: evidence from pecan (Carya illinoiensis K. Koch) - cotton (Gossipium hirsutum L.) alley cropping system in the southern United States. ForestEcology and Management 192:395-407.

Amthor JS (1986). Evolution and applicability of a whole plant respiration model. Journal of Theoretical Biology 122:473-90.

Bayala J, Teklehaimanot Z, Ouedraogo SJ (2004). Fine root distribution of pruned trees and associated crops in a parkland sysrem in Burkina Faso. AgroforestrySystems 60:13-26.

Banerjee H, Dhara PK, Mazumdar D (2009). Bamboo (Bambusa spp.) based agroforestry systems under rainfed upland ecosystem. Journal of Cropand Weed 5(1):286-290.

Berhongaray G, Janssens IA, KingJS, Ceuleman R (2013). Fine root biomass and turnover of two fast-growing poplar genotypes in a short rotation coppice culture. Plant and Soil 373:269-283.

Berhongaray G, Verlinden MS, Broeckx LS, Ceulemans R (2015). Changes in belowground biomass after coppice in two Populus genotypes. Forest Ecology and Management 337:1-10.

Bishopp A, Help H, Helariutta Y (2009). Cytokinin signaling during root development. International Review of Cell and Molecular Biology 276:1-48.

Bledsoe C, Fahey TJ, Ruess R, Day FP (1999). Measurement of static root parameters-biomass, length, distribution. In: Robertson GP, BledsoeCS, Coleman DC, Sollins P (Eds). Standard Soils Methods for Long-term Ecological Research, Oxford University Press, New York pp 413-435.

Block RMA (2004). Fine root dynamics and carbon sequestration in juvenile hybrid poplar plantations in Saskatchewan, Canada. M.Sc. Thesis, Univ. of Saskatchewan, Saskatoon, SK.

Block RMA, Van Rees CJ, Knight JD (2006). A review of fine root dynamics in Populus plantations. Agroforestry Systems 67:73-84.

Brunner I, Godbold DL (2007). Tree roots in a changing world. Journal of Forest Research 12:78-82.

Calfapietra C, Gielen B, Karnosky D, Ceulemans R, Scarascia-Mugnozza G (2010). Response and potential of agroforestry crops under global change. Environmental Pollution 158:1095-1104.

Callesen I,Harrison R, Stupak I, Hatten J, Raulund-Rasmussen K, Boyle J, Clarke N, Zabowski D (2016). Carbon storage and nutrient mobilization from soil minerals by deep roots and rhizospheres. Forest Ecology and Management 359:322-331.

Casper BB, Schenk HJ,Jackson RB (2003). Defining a plant's belowground zone of influence. Ecology 84(9):2313-2321.

Chauhan SK, Sharma R, Dhillon WS (2012). Status of intercropping in Poplar based agroforestry in India. ENVIS Forestry Bulletin, 12(1):4967.

Chen X, Eamus D, Hutley LB (2004). Seasonal patterns of fine root productivity and turnover in a tropical savanna of northern Australia. Journal of Tropical Ecology 20:221-224.

Christersson L (2010). Wood production potential in poplar plantations in Sweden. Biomass and Bioenergy 34(9):1289-1299.

Clark DA, Brown S, Kicklighter DW, Chambers JQ, Thomlinson JR, Ni J (2001). Measuring net primary production in forests: concepts and field methods. Ecological Applications 11:356-370.

Coutts MP, Nielsen CCN, Nicoll BC (1999). The development of symmetry, rigidity and anchorage in the structural root system of conifers. Plant and Soil 217:1-15.

Cooke JEK, Weih M (2005). Nitrogen storage and seasonal nitrogen cycling in Populus: bridging molecular physiology and ecophysiology. New Phytologist 167(1):19-30.

Danial O, Vitorino ACT, Alovisi AA, Mazzochin L, Tokura AM, Pinheiro ER, De-Souza EF (1997). Phosphorus application to Acacia mangium Willd. seedlings. Revista Arvore 21:163-168.

Das DK, Chaturvedi OP (2005). Structure and function of Populus deltoides agroforestry systems in eastern India: I. Dry matter dynamics. Agroforestry System 65:215-221.

Dickmann DI, Nguyen PV, Pregizzer KS (1996). Effects of irrigation and coppicing on above-ground growth, physiology, and fine root dynamics of two field-grown hybrid poplar clones. Forest Ecology and Management 80:163-74.

Dowell RC, Gibbins D, Rhoads JL, Pallardy SG (2009). Biomass production physiology and soil carbon dynamics in short-rotationgrown Populus deltoides and $P$. deltoides x $P$. nigra hybrids. Forest Ecology and Management 257:134142

Dougherty MC, Thevathasan NV, Gordon AM, Lee H, Kort J (2009). Nitrate and Escherichia coli NAR analysis in tile drain affluent from a mixed tree intercrop and monocrop system. Agriculture Ecosystem and Environment 131:77-84.

Douglas G, McIvor I, Potter JF, Foote L (2010). Root distribution of poplar at varyingdensities on pastoral hill country. Plant and Soil 333(1-2):147161.

Fang S, Xue J, TangL (2007). Biomass production and carbon sequestration potential in poplar plantations with different management patterns. Journal of Environmental Management 85:672-679.

Fang S, Xu X, Lu S, Tang L (1999). Growth dynamics and biomass production in short-rotation poplar plantations: 6-year results for three clones at four spacings. Biomass and Bioenergy 17:415-425.

Fortier J, Gagnon D, Truax B, Lambert F (2010). Biomass and volume yield after 6 years in multiclonal hybrid poplar riparian buffer strips. Biomass and Bioenergy 34:1028-1040.

Fortier J, Truax B, Gagnon D, Lambert F (2013). Root biomass and soil carbon distribution in hybrid poplar riparian buffers, herbaceous riparian buffers and natural riparian woodlots on farmland. SpringerPlus 2:539.

Fortier J, Truax B, Gagnon D, Lambert F (2015a). Biomass carbon, nitrogen and phosphorus stocks in hybrid poplar buffers, herbaceous buffers and 
430

natural woodlots in the riparian zone on agricultural land. Journal of Environmental Management 154:333-345.

Fortier J, Truax B, Gagnon D, Lambert F (2015b). Plastic Allometry in Coarse Root Biomass of Mature Hybrid Poplar Plantations. Bioenergy Research 8:1691-1704.

Friend AL, Jifon JL, Berrang PC, Seiler JR, Mobley JA (2000). Elevated atmospheric $\mathrm{CO}_{2}$ and species mixture alter $\mathrm{N}$ acquisition of trees in stand microcosms. Canadian Journal of Forest Research 30:827-36.

Friend AL, Scarasia-Mugnozza G, Iserbands JG, Heilmans PE (1991). Quantification of two-year-old hybrid poplar root systems: morphology, biomass, and 14C distribution. Tree Physiology 8:109-119.

Fukaki H, Tasaka M (2009). Hormone interactions during lateral root formation. Plant Molecular Biology 69:437-449.

Gary GRA (2000). Root distribution of hybrid poplar in a temperate agroforestry intercropping system. Master Thesis. University of Guelph, Canada. 116p.

Gera M (2012). Poplar culture for speedy carbon sequestration in India: A case study from Terai region of Uttarakhand. ENVIS Forestry Bulletin 12(1):75-83.

Guo L, Chen J, Cui X, Fan B, Lin H (2013). Application of ground penetrating radar for coarse root detection and quantification: a review. Plant and Soil 362(1-2):1-23.

Hallgren SW (1989). Growth response of Populus hybrids to flooding. Annales des Sciences foresti' eres 46:361-372.

Hansen K, Bastrup-Birk A, Bille-Hansen J, Vesterdal L, Gundersen P (2003). Kapitel 6 Jordbundens rolle i skoven. [Chapter 6. The role of soils in the forest. In Danish]. In: Hansen K(Ed). Næringsstofkredsløb i skove - Ionbalanceprojektet. Forest \& Landscape Research No. 332003. Danish Forest and Landscape Research Institute, Hørsholm.

Harrington CA, DeBell DS (1996). Above- and below- ground characteristics associated with wind toppling in a young Populus plantation. Trees 11:109-118.

Heilman PE, Ekuan G, Fogle D (1994). Above- and below-ground biomass and fine roots of 4 year-old hybrids of Populus trichocarpa $\times$ Populus deltoides and parental species in short-rotation culture. Canadian Journal ofForest Research 24(6):1186-1192.

Henderson R, Ford ED, Renshaw E, Deans JD (1983). Morphology of the structural root system of Sitka spruce 1. Analysis and quantitative description. Forestry 56:121-135.

Herve C, Ceulemans R (1996). Short-rotation coppiced vs. non-coppiced poplar: a comparative study at two different field sites. Biomass and Bioenergy 11:139-150.

Jansons A, Zurkova S, Lazdina D, Zeps M (2014). Productivity of poplar hybrid (Populus balsamifera $\times$ P. laurifolia) in Latvia. Agronomy Research 12(2):469-478.

Janssens IA, Sampson DA, Curiel-Yuste J, Carrara A, Ceulemans R (2002). The carbon cost of fine root turnover in a Scots pine forest. Forest Ecology and Management 168:231-40.

Jha KK, Gupta C (1991). Intercropping of medicinal plants with poplar and their phenology. Indian Forester 117:535-544.

Jha KK, (1999). Poplar (Populus deltoides) Farming. International Book DistributingCompany Lucknow, India.

Jha KK (2017). Biomass production and carbon balance in two hybrid
Poplar (Populus euramericana) plantations raised with and without agriculture in Southern France. Journal of Forestry Research, Accepted 29.06.2017.

Jiangen F, Zhong H, Harris W, Yu G, Wang S, Hu Z, Yue Y (2008). Carbon storage in the grasslands of China based on field measurements of above- and below- ground biomass. Climatic Change 86:375-396.

John B, Pandey HN, Tripathi RS (2001). Vertical distribution and seasonal changes of fine and coarse root mass in Pinus kesiya Royle Ex. Gordon forest of three different ages. Acta Oecologica 22 (5-6):293-300.

Jose S, Bardhan S (2012). Agroforestry for biomass production and carbon sequestration: an overview. Agroforestry Systems 86:105-111.

Kalliokoski T, Nygren P, Sievänen R (2008). Coarse Root Architecture of Three Boreal Tree Species Growing in Mixed Stands. Silva Fennica 42(2):189-210.

Kell DB (2012). Large-scale sequestration of atmospheric carbon via plant roots in natural and agricultural ecosystems: why and how. Philosophical Transaction of Royal Society B 367:1589-97.

Kellman M (1979). Soil enrichment of neotropical savanna trees. Journal of Ecology 67:565-577.

Kern CC, Friend AL, Johnson JMF, Coleman MD (2004). Fine root dynamics in a developing Populus deltoides plantation. Tree Physiology 24:651-660.

Konopka B, Curiel-Yuste J, Janssens IA, Ceulemans R(2005). Comparison of fine root dynamics in Scots pine and pedunculate oak in sandy soil. Plant and Soil 276:33-45.

Konopka B, Noguchi K, Sakata T, Takahashi M, Konopkova Z (2006). Fine root dynamics in a Japanese cedar (Cryptomeria japonica) plantation throughout the growing season. Forest Ecology and Management 225:278-86.

Kumar R, Pandey S, Pandey A (2006). Plant roots and carbon sequestration. CurrentScience 91(7):885-890.

Laclau P (2003). Root biomass and carbon storage of ponderosa pine in a northwest Patagonia plantation. Forest Ecology and Management 173:353-360.

Lambers H, Chapin III FS, Pons TL. (2000). Plant physiological ecology. 1st ed. New York: Springer; p. 540.

Langeveld H, Quist-Wessel F, Dimitriou I, Aronsson P, Baum C, Schulz U, Bolte A, Baum S, Kohn J, Weih M, Gruss H, Leinweber P, Lamersdorf N, Schmidt-Walter P, Berndes G (2012). Assessing environmental impact of short station coppice (SRC) expansion: model definition and preliminary results. Bioenergy Research 5:621-635.

Laureysens I, Bogaert J, Blust R, Ceulemans R (2004). Biomass production of 17 poplar clones in a short-rotation coppice culture on a waste disposal site and its relation to soil characteristics. Forest Ecology and Management 187(2-3):295-309.

Levillain J, M'Bou AT, Deleporte P, Saint-Andre L, Jourdan C (2011). Is the simple auger coring method reliable for belowground standing biomass estimation in Eucalyptus forest plantation? Annals of Botany 108:221230.

Lodhiyal LS, Singh RP, Singh SP (1995). Structure and Function of an Age Series of Poplar Plantations in Central Himalaya: Dry Matter Dynamics. Annals of Botany 76:191-199.

Lukac M, Calfapietra C, Godbold DL (2003). Production, turnover and 
mycorrhizal colonization of root systems of three Populus species grown under elevated $\mathrm{CO}_{2}$ (POPFACE). Global Change Biology 9:838-48.

Malhi Y, Doughty C, Galbraith D (2011). The allocation of ecosystem net primary productivity in tropical forests. Philosophical Transactions of Royal Society B 366:3225-3245.

McIvor IR, Metral B, Douglas GB (2005). Variation in root density of poplar trees at different plant densities. Agronomy New Zealand Journal 35:66-73.

McIvor IR, Douglas GB, Benavides R (2009). Coarse root growth of Veronese poplar trees varies with position on an erodible slope in New Zealand. Agroforestry Systems 76:251-264.

Millikin CS, Bledsoe CS (1999). Biomass and distribution of fine and coarse roots from blue oak (Quercus douglasii) trees in the northern Sierra Nevada foothills ofCalifornia. Plant and Soil 214:27-38.

Misra RK, Turnbull CRA, Cromer RN, Gibbons AK, LaSala AV (1998). Below- and above- ground growth of Eucalyptus nitens in a young plantation: I. Biomass. ForestEcology and Management 106:283-293.

Moreno G, Obrador JJ, Cubera E, Dupraz C (2005). Fine root distribution in dehesas ofCentral Western Spain. Plant and Soil 277:153-162.

Moreno-Chacon M, Lusk C (2004). Vertical root distribution of fine root biomass of emergent Nathofagus dombeyi and its canopy associates in a Chilean rainforest. Forest Ecology and Management 199:177-181.

Mulia R, Dupraz C (2006). Unusual fine root distributions of two deciduous tree species in southern France: What consequences for modelling of tree root dynamics? Plant and Soil 281:71-85.

Mulia R (2005). Modelisation tri-dimensionelle de la croissance du systeme racinaire des plantes en milieu heterogene avec l'approche de l'automate voxellaire. Universite de Montpellier II. Ph D Thesis: 86p.

Nair PKR, Nair VD, Kumar BM, Haile SG (2009). Soil carbon sequestration in tropical agroforestry systems: a feasibility appraisal. Environmental Science and Policy 12:1099-1111.

Niiyama K, Kajimoto T, Matsuura Y, Yamashita T, Matsuo N, Yashiro Y, Ripin A, Kassim AR, Noor NS (2010). Estimation of root biomass based on excavation of individual root systems in a primary dipterocarp forest in Pasoh Forest Reserve, Peninsular Malaysia. Journal of Tropical Ecology 26:271-284

Ostonen I, Löhmus K, Pajuste K (2005). Fine root biomass, production and its proportion of NPP in a fertile middle-aged Norway spruce forest: Comparison of soil core and ingrowth core methods. Forest Ecology and Management 212:264277.

Paul KI, Polglase JG, Nyakuengama JG, Khanna PK (2002). Change in soil carbon following afforestation. Forest Ecology and Management 168:241e 57.

Perry TO (1989). Tree roots: Facts and Fallacies. Arnoldia 49(4):3-29.

Pingale B, Bana OPS, Banga A, Chaturvedi S, Kaushal R, Tewari S, Neema (2014). Accounting biomass and carbon dynamics in Populus deltoides plantation under varying density in Tarai of central Himalaya. Journal of TreeScience 33(2):1-6.

Pinno BD, Wilson SD, Steinaker DF, VanRees KCJ, McDonald SA (2010). Fine root dynamics of trembling aspen in boreal forest and aspen parkland in central Canada. Annals of Forest Science 67:710-716.

Post WM, Kwon KC (2000). Soil carbon sequestration and land-use change: processes and potential. Global Change Biology 6:317e27.
Purbopuspito J, Rees K (2002). Root distribution and various distances from clove trees growingin Indonesia. Plant and Soil 239:313-320.

Puri S, Singh V, Bhushan B, Singh S (1994). Biomass production and distribution of roots in three stands of Populus deltoides. Forest Ecology and Management 65:135-147.

Raich JW, Clark DA, Schwendenmann L, Wood TE (2014). Aboveground tree growth varies belowground carbon allocation in a tropical rainforest environment. PLOS ONE 9:e100275 http://dx.doi.org/10.1371/journal.pne.0100275.

Raizada A, Jayaprakash J, Rathore AC, Tomar JMS (2013). Distribution of fine root biomass of fruit and forest tree species raised on old river bed lands in north western Himalaya. Tropical Ecology 54(2):251-261.

Resh S, Battaglia M, Worledge D, Ladiges S (2003). Coarse root biomass for eucalypt plantations in Tasmania, Australia: sources of variation and methods for assessment. Trees 17(5):389-399.

Rood SB, Bigelow SG, Hall AA (2011). Root architecture of riparian trees: river cut-banks provide natural hydraulic excavation, revealing that cottonwoods are facultative phreatophytes. Trees 25:907-917.

Rosengren U, Göransson H, Jönsson U, Stjernquist I, Thelin G, Wallander $\mathrm{H}$ (2006). Functional biodiversity aspects on the nutrient sustainability in forests -importance of root distribution. Journal of Sustainable Forestry 21(2-3):77-100.

Singh B, Sharma KN (2007). Tree growth and nutrient status of soil in a poplar (Populus deltoides Bartr.) based agroforestry system in Punjab, India. Agroforestry Systems 70:125-134.

Singh K, Chauhan HS, Rajput DK, Singh DV (1989). Report of a 60 month study on litter production, changes in soil chemical properties and productivity under Poplar (P. deltoides) and Eucalyptus (E. hybrid) interplanted with aromatic grasses. Agroforestry Systems 9:37-45.

Singh P, Singh B (2016). Biomass and nitrogen dynamics of fine roots of poplar under differential $\mathrm{N}$ and $\mathrm{P}$ levels in an agroforestry system in Punjab. Tropical Ecology 57(2):143-152.

Smith AR, Lukac M, Bambrick M, Miglietta F, Godbold DL (2013). Tree species diversity interacts with elevated $\mathrm{CO} 2$ to induce a greater root system response. Global Change Biology 19:217-228.

Smith D, Jackson N, Roberts J, Ong C (1999). Root distributions in a Grevillea robusta - maize agroforestry system in semiarid Kenya. Plant and Soil211:199-205.

Smith DM (2001). Estimation of tree root length using fractal branching rules: a comparison with soil coring for Greveillea robusta. Plant and Soil 229:295-301.

Spinelli R, Nati C, Magagnotti N (2008). Harvesting short rotation poplar plantation for biomass production. Croatian Journal of Forest Engineering 29(2):129-139.

Steele SJ, Grower ST, Vogel JG, Norman JM (1997). Root mass, net primary production and turnover in aspen, jack pine and black spruce forest in Saskatchewan and Manitoba, Canada. Tree Physiology 17:577-587.

Tomlinson H, Traore A, Teklehaimanot Z (1998). An investigation of the root distribution of Parkia biglobosa in Burkina Faso, West Africa, using a logarithmic spiral trench. Forest Ecology and Management 107:173182.

Truax B, Gagnon D, Fortier Julien, Lambert F (2012). Yield in 8 year-old 
432

hybrid poplar plantations on abandoned farmland along climatic and soil fertility gradients. Forest Ecology and Management 267:228239.

Tufekcioglu A, Raich JW, Isenhart TM, Schultz RC(2003). Biomass, carbon and nitrogen dynamics of multi-species riparian buffers within an agricultural watershed in Iowa, USA. Agroforestry Systems 57(3):187-198.

Venendaal R, Jorgensen U, Foster CA (1997). European energy crops: a synthesis. Biomass and Bioenergy 13:147-185.

Verwijst T (2001). Willows: an underestimated resource for environment and society. Forestry Chronicle 77:281-285.

Watson A, O'Loughlin C (1990). Structural root morphology and biomass of three age classes of Pinus radiata. NewZeal Journal of Forestry Science 20:97-110.
Wullschleger SD, Yin TM, DiFazio SP, Tschaplinski TJ, Gunter LE, Davis MF, Tuskan GA (2005). Phenotypic variation in growth and biomass for two advanced-generation pedigrees of hybrid poplar. Canadian Journal of Forest Research 35:1779-1789.

Yocum WW (1937). Root development of young delicious apple trees as affected by soil and cultural treatment. University of Nebraska Agriculture ExperimentStation, Research Bulletin, 95:1-55.

Zabek L, Prescott C (2006). Biomass equations and carbon content of aboveground leafless biomass of hybrid poplar in Coastal British Columbia. Forest Ecology and Management 223:291-302. 